\title{
Water bears dominated cryoconite hole ecosystems: densities, habitat preferences and physiological adaptations of Tardigrada on an alpine glacier
}

\author{
Krzysztof Zawierucha $(\mathbb{D} \cdot$ Jakub Buda $\cdot$ Roberto Sergio Azzoni • \\ Małgorzata Niśkiewicz $\cdot$ Andrea Franzetti $\cdot$ Roberto Ambrosini $($ D
}

Received: 8 April 2019/Accepted: 29 June 2019/Published online: 13 July 2019

(C) The Author(s) 2019

\begin{abstract}
We investigated the Forni Glacier and the surrounding area in the Alps in terms of habitat preferences, densities, dispersal and desiccation tolerance of glacier tardigrades, which are one of the most common faunal representatives and top consumers in supraglacial ecosystems. To do so, we sampled supraglacial environments (cryoconite holes, debris from ice surface, dirt cones and moraine, mosses from supraglacial stones) and non-glacial habitats (mosses, freshwater sediments and algae), and we installed air traps on the glacier and the nearby area. We found that cryoconite holes on the Forni Glacier are exclusively dominated by one metazoan group of tardigrades, representing one species, Hypsibius klebelsbergi (identified by morphological and
\end{abstract}

Handling Editor: Télesphore Sime-Ngando.

Electronic supplementary material The online version of this article (https://doi.org/10.1007/s10452-019-09707-2) contains supplementary material, which is available to authorized users.

K. Zawierucha $(\bowtie) \cdot$ J. Buda

Department of Animal Taxonomy and Ecology, Adam

Mickiewicz University, Poznań, Uniwersytetu

Poznańskiego 6, 61-614 Poznan, Poland

e-mail: k.p.zawierucha@gmail.com

R. S. Azzoni · R. Ambrosini

Department of Environmental Science and Policy,

University of Milan, Via Celoria 26, 20133 Milan, Italy molecular approaches). Tardigrades were found in $100 \%$ of cryoconite holes and wet supraglacial sediment samples and reached up to $172 \mathrm{ind} . / \mathrm{ml}$. Additionally, we found glacier tardigrades in debris from dirt cones and sparsely in supraglacial mosses. Glacier tardigrades were absent from freshwater and terrestrial samples collected from non-glacial habitats. Despite the fact that H. klebelsbergi is a typical aquatic species, we showed it withstands desiccation in sediments, but in low temperatures only. Treatments conducted in higher temperatures and water only showed low or no recovery. We suspect successful dispersal with wind might have taken place only when tardigrades desiccated in sediments and were passively transported by cold wind. Limited ability to withstand high temperatures and desiccation may be potential barriers preventing glacier tardigrades inhabiting new, even apparently suitable high mountain water bodies like temporary rock pools.

\footnotetext{
M. Niśkiewicz

Evolutionary Biology Group, Adam Mickiewicz University, Poznań, Uniwersytetu Poznańskiego 6, 61-614 Poznan, Poland
}

\footnotetext{
A. Franzetti

Department of Earth and Environmental Sciences (DISAT), University of Milano-Bicocca, Piazza Della Scienza, 1, 20126 Milan, Italy
} 
Keywords Cryobiosis - Cryoconite holes ·

Desiccation · Dispersal · Dirt cones · Extremophiles . Supraglacial habitats

\section{Introduction}

Glaciers and ice sheets are considered to be a peculiar biome characterised by permanently low temperatures and unique cold-adapted organisms (Hodson et al. 2008; Anesio and Laybourn-Parry 2012). The most biologically active part of glacial ecosystems is the supraglacial zone (the surface of glaciers), where during summer the interaction of psychrophilic bacteria and algae along with mostly wind-blown dust form a layer of cryoconite (named from Greek 'kryos' — cold, 'konis' - dust) and influence the darkening of ice and the melting of water-filled reservoirs called cryoconite holes (Wharton et al. 1985; Takeuchi et al. 2000; Hodson et al. 2008; Cook et al. 2016). Cryoconite holes host unique assemblages mostly of bacteria, algae and microfauna different from the ones found in ice-free areas (Stibal et al. 2015; Franzetti et al. 2017; Ambrosini et al. 2017; Liu et al. 2017; Zawierucha et al. 2018a, b). These specific reservoirs constitute glacial biodiversity hot spots and bioreactors responsible for organic matter production and also play an important role in glacier mass balance, glacial geochemistry, carbon cycling and as a storage of various pollutants (Mueller et al. 2001; Fountain et al. 2004; Bagshaw et al. 2007; Stibal et al. 2010; Pittino et al. 2018; Łokas et al. 2018; Zawierucha et al. 2018a, 2019a). Cryoconite holes are one of the most extreme freshwater ecosystems on Earth characterised by permanently low temperatures, frequent disturbance due to rain and flushing of melting water and periodic freezing (Mueller et al. 2001; Zawierucha et al. 2019b). However, despite harsh conditions, the diversity of biota is relatively high, and trophic relations form simple, truncated webs, where invertebrates function as apex consumers (Hodson et al. 2008; Zawierucha et al. 2018a, 2019a). One of the common invertebrate taxa known to inhabit glacier surfaces in the Arctic, Antarctic, Central Asia and the Alps are tardigrades (Dastych et al. 2003; Porazińska et al. 2004; Zawierucha et al. 2016, 2019a).

Tardigrada (also known as water bears) is a phylum of micrometazoans of mostly ca. $50-1200 \mu \mathrm{m}$ in size.
So far, more than 1300 tardigrade species have been described worldwide (Nelson et al. 2015; Degma et al. 2019; McInnes and Pugh 2019). As a result of their evolutionary history, their tolerance to unfavourable conditions, small size and probable long-range distance dispersion by wind, they inhabit a variety of environments, such as limno-terrestrial (soil, mosses, lichens) and aquatic (sediments, plants), including extreme polar and high mountain ecosystems (Kaczmarek et al. 2016; Nelson et al. 2015; McInnes et al. 2017). Tardigrades play an important role in trophic webs at a multitrophic level as carnivorous, omnivorous, herbivorous and microbivorous species (Hallas and Yeates 1972; Guidetti et al. 2012a; Guil and Sanchez-Moreno 2013). In some Antarctic ecosystems, such as nunataks or coastal plains, as well as glaciers in the Arctic and Antarctic, tardigrades are dominant or even the only metazoans and exist as the highest trophic consumers (Convey and McInnes 2005; Zawierucha et al. 2016). Tardigrades reach high densities in cryoconite (Zawierucha et al. 2019a), and due to grazing, they may potentially influence the diversity and density of other organisms inhabiting cryoconite holes (Zawierucha et al. 2016, 2018a). Their species richness in extreme glacial habitats is known to be low in comparison with that of tundra or high mountain invertebrate communities, potentially as a consequence of a strong selection pressure of the cryosphere (e.g. Zawierucha et al. 2016, 2019b).

There is a strong need to recognise the extent to which the biogeography of tardigrades on glaciers and surrounding habitats is driven by dispersal limitations, habitat selection and local (physiological) adaptations. The colonisation of low-temperature habitats by invertebrates requires adaptations to cold and freezing stress (Dastych et al. 2003; Convey et al. 2014, 2018; Dial et al. 2016; Shain et al. 2016; Zawierucha et al. 2018b). Distinctly freshwater tardigrade species undergo limited or no cryptobiosis, and information on their dispersal is based on assumptions without experimental evidence (Nelson et al. 2019). The dispersal of glacier tardigrades between glaciers was previously suggested by Zawierucha et al. (2018b) and Dabert et al. (2015). Moreover, as was shown by Zawierucha et al. (2018b), a new genus Cryoconicus found on glaciers in central Asia recovered after 11 years in a frozen state, which suggests that cryobiosis is an adaptive benefit for glacier tardigrades subjected to periodic freezing. Cryoconite tardigrades 
in the Alps seem to be a good model to present how physiological barriers prevent settling new habitats suitable at first sight and what is the role of other adaptations, for instance desiccation, in dispersal strategies. Therefore, we investigated habitat preferences, densities and desiccation tolerance of tardigrades on the Forni Glacier in the Alps during the middle of summer 2018. Despite the fact that the understanding of cryoconite holes and glacial ecosystems is increasing (Cook et al. 2015; Pittino et al. 2018; Perini et al. 2019; Takeuchi et al. 2018), the knowledge on tardigrades inhabiting them is still far from satisfactory and may limit our understanding of the functions, dynamics and trophic relations in supraglacial ecosystems. Therefore, all knowledge on organism's dynamics, dispersal and interactions with ice must be acquired in order to understand biological aspects of the glacial biome (Hodson et al. 2015; Cook et al. 2015, 2016). As a model, we used tardigrades in alpine cryoconite holes that contain these common, relatively large, black animal, which facilitates their observations.

The ecology and biology of cryoconite holes on Forni have been the subject of intensive studies with the majority of recent works focusing on the diversity, ecology and metabolism of bacteria (Franzetti et al. 2016, 2017; Ferrario et al. 2017; Pittino et al. 2018). Franzetti et al. (2017) showed that moraines may act as sources of bacteria for cryoconite holes on Forni, but different conditions limit them, and at the same time, holes are inhabited by unique bacterial strains known only from glaciers. Comparably, tardigrades from tundra and Arctic cryoconite holes show unique assemblages of animals on glaciers (Zawierucha et al. 2016). A similar phenomenon on glaciers in Austria was suggested by Dastych et al. (2003). However, tardigrade adaptations for dispersal as well as their distribution and habitat preferences still remain a topic of debate (Guil et al. 2009; Gąsiorek et al. 2019; McInnes and Pugh 2019; Rivas et al. 2019; Zawierucha et al. 2018b). Until now, tardigrades in glacial habitats were mostly investigated in cryoconite holes with scarce data on other glacial habitats (Dastych et al. 2003; Coulson and Midgley 2012). In this study, we focused on various terrestrial (mosses), freshwater (cryoconite, sediments, submerged plants) and semiterrestrial (debris mixed with cryoconite on glacier) habitats and investigated the distribution, densities, dispersal and physiological adaptations of tardigrades on Forni Glacier. Our primary assumption was that, due to different environmental conditions, the diversity of tardigrades in cryoconite holes differs when compared to the diversity in the surrounding non-glacial water bodies and terrestrial samples. We also expected that typical aquatic tardigrades on glaciers will not be able to survive desiccation but, as cryophilic species, will survive low and avoid high temperatures.

\section{Methods}

Sampling and extraction of invertebrates

Forni Glacier in the Ortles-Cevedale group (Stelvio National Park, Central Italian Alps) is one of the largest Italian glaciers (Fig. 1). The area of Forni is $10.83 \mathrm{~km}^{2}$. Its elevation ranges between 2600 and $3670 \mathrm{~m}$ a.s.l. (Azzoni et al. 2017).

Cryoconite was collected from the bottom of cryoconite holes (Fig. 2a, b) during sampling campaigns in ablation seasons of 2012, 2017 and 2018. The samples were collected with independent disposable plastic Pasteur pipettes or a stainless spoon and transferred into $15-\mathrm{cm}^{3}$ plastic test tubes. In order to check for fine-scale spatial heterogeneity of tardigrades in the cryoconite holes, we collected nine subsamples located in three rows on the holes' floor, from three cryoconite holes in 2018 (Fig. 2b, for details see Zawierucha et al. 2019a). The cryoconite was stored in $75 \%$ ethylene alcohol or frozen and transported to a laboratory at Adam Mickiewicz University, Poznań. In the laboratory, after the cryoconite material had settled in the tubes (i.e. after at least $30 \mathrm{~min}$ ), only the sediment was analysed. The amount of sediment used for analysis was estimated based on the measure of the plastic tube.

Other supraglacial material [debris from a glacier surface (mixed with cryoconite), debris from dirt cones and from the medial moraine and no glacial (terrestrial (mosses), freshwater (sediments, algae, submerged mosses)] was collected between 20-24 July 2018 (Figs. 2c-f, S1 A-D). Moss samples were collected, placed in paper envelopes and allowed to dry slowly. Freshwater and semiterrestrial samples were stored with $75 \%$ alcohol in plastic tubes and containers. Debris from the medial moraine and dirt cones were collected in plastic zip bags and kept in 
Fig. 1 Map of the study area: Forni Glacier and the proglacial area located in the Italian Alps

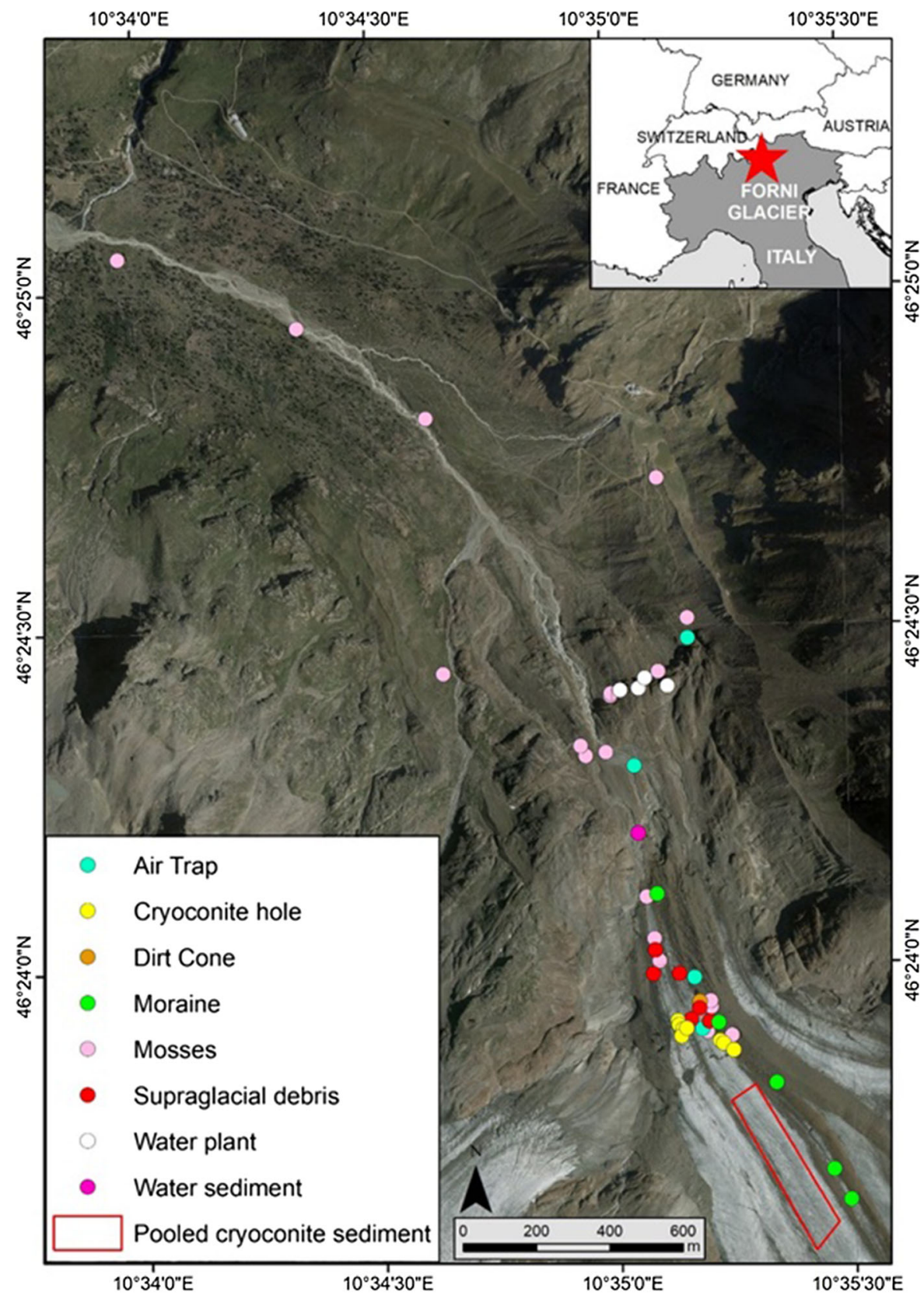

low temperatures until the isolation of fauna with the use of Tullgren funnels at Adam Mickiewicz University, Poznan. The rest of the samples (cryoconite, mosses, algae, dirt cones and supraglacial debris) were examined for invertebrates using standard methods of extraction described by Dastych (1980) and Degma (2019): animals were isolated by placing the material in a beaker filled with $200 \mathrm{ml}$ of water. After ca. $6 \mathrm{~h}$, mosses were vigorously shaken and comminuted in the beaker. The rest of material was analysed without keeping material for a longer time in beaker. Then, the material was separated optically in the beaker and the supernatant containing invertebrates inhabiting the investigated material was stirred and poured into a 250-ml cylinder. After sedimentation, ca. $50 \mathrm{ml}$ of precipitate was stirred, poured into glass Petri dishes and examined, and specimens were counted under a stereomicroscope. 

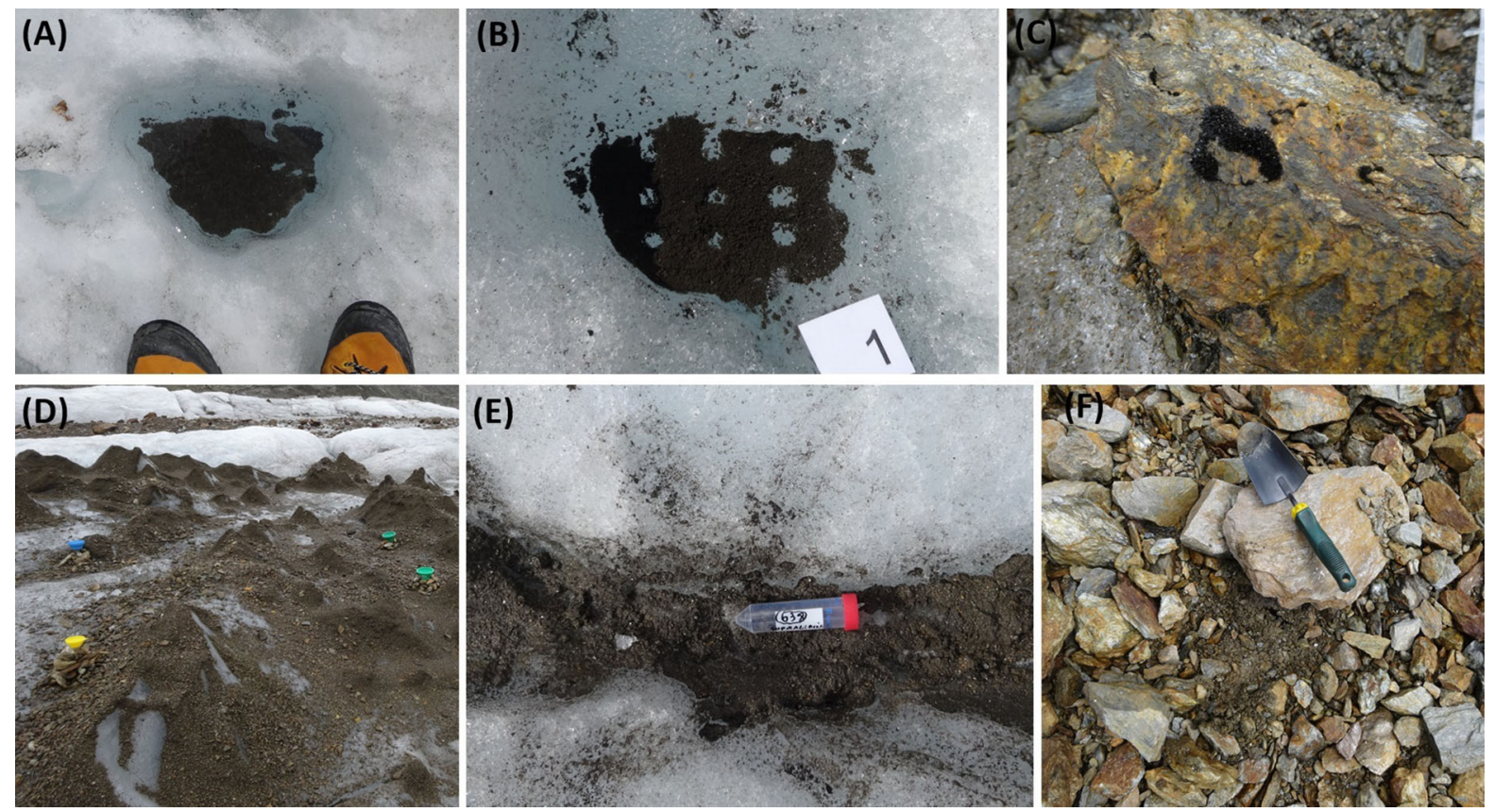

Fig. 2 Examples of sampled supraglacial habitats: a, b cryoconite hole, $\mathbf{c}$ mosses on supraglacial boulders, $\mathbf{d}$ dirt cones, e supraglacial debris (mixture of mineral debris and cryoconite), $\mathbf{f}$ debris/gravel from medial moraine

Aeroplankton traps were made from funnels mounted in plastic boxes and installed above the surface of the glacier, on the median moraine, on the proglacial plain and in a transition zone between the proglacial plain and the main valley (Figs. 1, 2d, S1 A). The plastic boxes were filled with $75 \%$ alcohol, controlled every day and re-filled with alcohol, if needed. The traps were installed between 20-23 July 2018. Two types of traps were mounted: 13 and $7.5 \mathrm{~cm}$ in diameter.

The samples ready for analysis were scanned for the presence of invertebrates in Petri dishes scored with perpendicular lines (which enabled a more accurate analysis of the sediment) via a stereomicroscope (Olympus SZ51). The total number of tardigrades from cryoconite holes was converted to a density measurement of individuals per $1 \mathrm{~cm}^{3}$ of cryoconite. The rest of the animals are presented as approximate estimated values (see Tables S2-S6, S8).

Morphological and molecular identification of tardigrades

With the classical (morphological) approach in tardigrade identification, we used the original description of Mihelčič (1959) as well as the redescription of Hypsibius klebelsbergi in Dastych et al. (2003). DNA was isolated using the DNeasy Blood and Tissue Kit (Qiagen $\mathrm{GmbH}$, Hilden, Germany) from eight individuals randomly isolated from four samples as following the protocol in Dabert et al. (2008). A fragment of the mitochondrial cytochrome c oxidase subunit I (COI) gene was amplified with a bcdF01 forward primer (CATTTTCHACTAAYCATAARGATATTGG) and bcdR04 reverse primer (TATAAACYTCDGGATGNCCAAAAAA) (Dabert et al. 2008). Polymerase chain reaction (PCR) amplifications were carried out in a total volume of $10.0 \mu \mathrm{l}: 5 \mu \mathrm{l}$ Type-it Microsatellite PCR Kit (Qiagen), $0.5 \mu$ of each primer and $4 \mu \mathrm{l}$ of the DNA template. The PCR programme for COI followed Dabert et al. (2015). Diluted PCR product was analysed by electrophoresis on $1 \%$ agarose gel. Samples containing visible bands were purified with exonuclease I and Fast alkaline phosphatase (Fermentas). The PCR product was prepared for sequencing in a total volume of $6.0 \mu \mathrm{l}$ containing: $1.5 \mu \mathrm{l}$ primer, $1.5 \mu \mathrm{l}$ purified PCR product and $3 \mu \mathrm{M}$ MQ water, and sequenced using the BigDye Terminator v3.1 kit and the ABI Prism $3130 \times 1$ 
Genetic Analyzer (Applied Biosystems), following the manufacturer's instructions.

To calculate molecular distances for the COI fragments, sequences were obtained from GenBank for Hypsibius klebelsbergi Mihelčič 1959 [GenBank accession numbers: KT901831, KT901834 deposited by Dabert et al. (2015)]. Sequences were processed in BioEdit ver.7.2.5 (Hall 1997). Pairwise distances between nucleotide sequences were calculated using a distance model for all codon positions as implemented in MEGA 7 (Kumar et al. 2016).

Experiment on temperature and desiccation tolerance

Samples of cryoconite for further laboratory experiments were collected in 50-ml vials, between 20-24 July 2018 in the upper part of the tongue of Forni (Fig. 1). Samples from many randomly chosen cryoconite holes were pulled together (such strategies increased the abundance of tardigrades required for analysis). Subsequently, after sampling, the material was frozen and transported to the laboratory at the Faculty of Biology (Adam Mickiewicz University, Poznań). The material was melted and kept in glass beakers at $3{ }^{\circ} \mathrm{C}$ for 1 month. Tardigrades which recovered from cryobiosis were individually placed onto 24-well plastic plates for further experiments. Due to the sensitivity of glacier tardigrades to higher temperatures (see Results and Discussion), for experiments, we extracted tardigrades under stereo microscopes placing the samples on ice or ice packs. In the first experiment, we focused on how glacier tardigrades respond to desiccation under low $\left(3{ }^{\circ} \mathrm{C}\right)$ and high temperature (room temperature, $16-20{ }^{\circ} \mathrm{C}$ ). They were divided into two trials: animals kept in water only ( $N=91$ for low temp., $N=36$ for room temp.) and animals kept in water with cryoconite (water/cryoconite, $N=72$ for low temp. and $N=56$ for room temp.) at the bottom of the plastic wells. One millilitre of commercial bottle water (Pepsi Cola General Bottlers Poland Sp. z o.o., ul. Fort Wola 22, 0-961 Warszawa) and a little cryoconite (depending on the treatment) were added to each well. Open plates with water and water/cryoconite were kept for 1 week in low and room temperature until the weels were completely dry. After 7 days, we added a millilitre of the same water to each well, waited $24 \mathrm{~h}$ and investigated each weel to assess tardigrade viability.
Tardigrades were classified as successfully recovered when they were moving and crawling on the bottom of a well. The second experiment was conducted in low temperatures only. Treatments were divided into: tardigrades kept with water only $(N=67)$, little cryoconite $(N=51)$, abundant cryoconite $(N=54)$, little sand $(N=56)$, abundant sand $(N=62)$. We decided to use sand with water as material devoid of organic matter (potential food) but still able to maintain moisture longer during drying than treatment with water only. Always cryoconite and sand were transferred to one millilitre of water. The amount of cryoconite and sand used for experiment was estimated by the number of small scoops which were used for transferring the material (scoop size: 1 centimetre long by 0.5 width). The same laboratory protocol for animals' observation as for the first study was used.

\section{Results}

Fauna in particular habitats

The entire cryoconite investigated in cryoconite holes was dominated by one tardigrade species Hypsibius klebelsbergi (also called glacier tardigrade herein, Fig. 3). The densities of $H$. klebelsbergi reached up to 172 ind./ml (Table 1, S1). Hypsibius klebelsbergi was found in $100 \%$ of cryoconite samples from cryoconite holes and the mixture of cryoconite and gravel on a glacier's surface (Fig. 4, Tables S1, S3). Even when up to nine subsamples were collected from three cryoconite holes (Fig. 2b), each subsample contained tardigrades. Glacier tardigrades were also sporadically found in supraglacial mosses and debris from dirt cones (mostly damaged specimens, Fig. 4, Tables S2, S4). Glacier tardigrades were absent from freshwater and terrestrial samples collected from non-glacial habitats such as mosses, sediments and algae. Yet, other limno-terrestrial tardigrades were found within these samples, along with other representatives of aquatic and terrestrial invertebrates (Tables S2, S3, S4, S6). One glacier tardigrade was found in debris collected from the medial moraine (Table S5). Wet samples from the medial moraine were dominated by springtails, apart from a single tardigrade, two specimens of mites and one insect (Table S5). Raw data for abundance of $H$. klebelsbergi in cryoconite holes and 


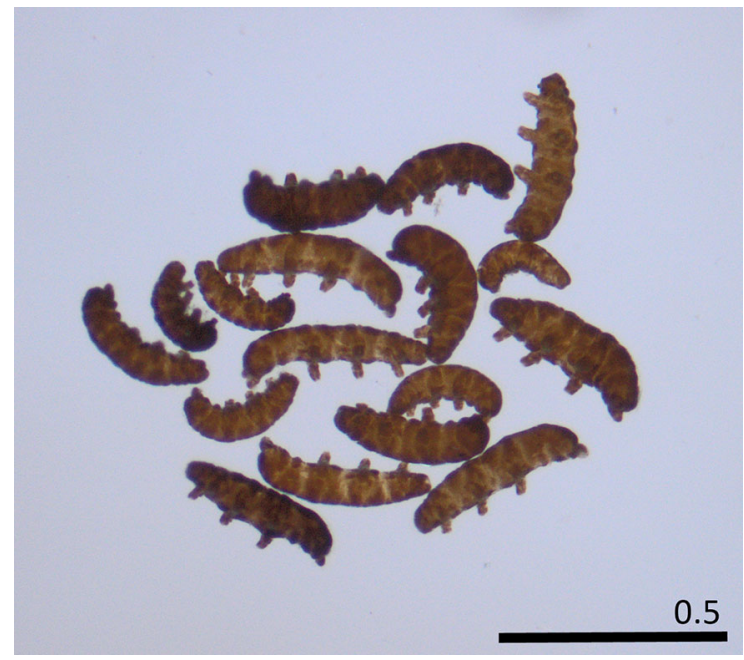

Fig. 3 Specimens of Hypsibius klebelsbergi isolated from cryoconite holes (scale given in millimetre)

Table 1 Descriptive statistics for tardigrade Hypsibius klebelsbergi densities from cryoconite holes on Forni

\begin{tabular}{llllll}
\hline & $\mathrm{N}$ & MIN & MAX & MEAN & SD \\
\hline Tardigrada per 1 ml & 23 & 2.22 & 172 & 48.16 & 39.74
\end{tabular}

Data exclude a big amount of pulled cryoconite from many holes (see methods for details)

$N$ number of sampled cryoconite holes associated environmental variables are presented in Table S1.

Seven sequences for $H$. klebelsbergi obtained in this study were unique and distinct from all the other sequences deposited in GenBank. The COI alignment comprised $521 \mathrm{bp}$ including all sequences obtained in this study and two deposited by Dabert et al. (2015, accession numbers: KT901831 and KT901834) with 9 haplotypes (the uncorrected $p$-distances varied from 0.2 to $1.8 \%$ ) (sequences deposited in GenBank under accession numbers: MN052996-MN053003). One of haplotype in the alignment (KT901831) found in this study was previously found on Langtaler Ferner and Ramolferner located, respectively, 50 and $60 \mathrm{~km}$ north-east from Forni Glacier (Tables 2, S7).

Black-pigmented springtails were found on the surface of water in cryoconite holes in apparently random locations, probably because they were flushed from surface of glacier (Figure S2 C). We often observed old and damaged specimens of springtails in the sediments. However, there were abundant under supraglacial stones. Additionally, accidentally windblown remains of insects or the whole individuals (not active) were found between cryoconite granules (Figures S2 A,B). Only few rotifers were found in the entire cryoconite material we investigated for both counting the densities of tardigrades in the holes and for desiccation experiments (pooled sample).
Fig. 4 Occurrence of tardigrades (Tardigrada: Hypsibius klebelsbergi), rotifers (Rotifera) and springtails (Collembola) in particular kind of samples: Cryoconite material from cryoconite holes, Mosses collected from supraglacial stones, Debrissupraglacial gravel mixed with cryoconite, and gravel from Dirt cones (for details see Tables S 2-4)

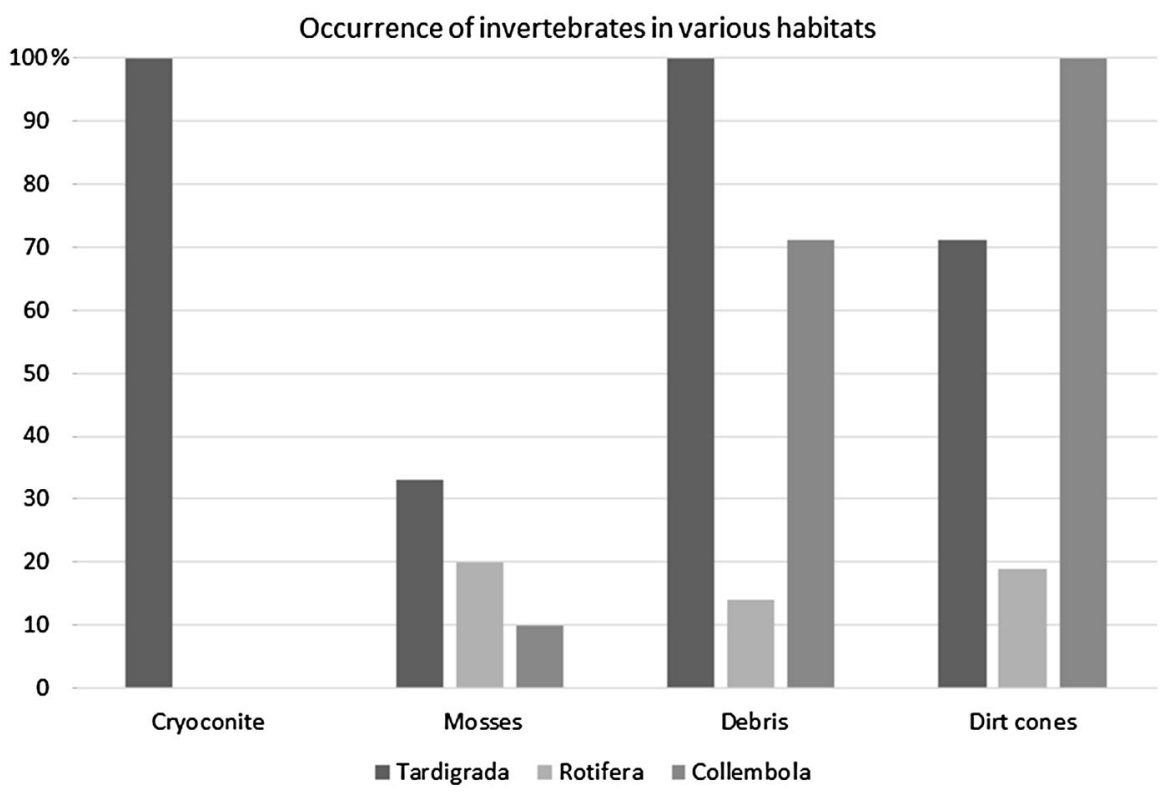


Table 2 Genetic distances between specimens from Forni (this study) and Langtalerferner and Ramolferner glaciers (Dabert et al. 2015)

\begin{tabular}{|c|c|c|c|c|c|c|c|c|c|c|}
\hline \multirow{2}{*}{$\begin{array}{l}\text { Table } 2 \text { Genetic distances } \\
\text { between specimens from }\end{array}$} & & & & & & & & & & \\
\hline & & $F$ & $F$ & $F$ & $F$ & $F$ & $F$ & $F$ & $F$ & KT901831 \\
\hline Forni (this study) and & $F$ & & & & & & & & & \\
\hline Langtalerferner and & $F$ & $1.8 \%$ & & & & & & & & \\
\hline (Dabert et al. 2015) & $F$ & $1.4 \%$ & $0.4 \%$ & & & & & & & \\
\hline & $F$ & $1.6 \%$ & $0.2 \%$ & $0.2 \%$ & & & & & & \\
\hline & $F$ & $1,8 \%$ & $0,8 \%$ & $0.4 \%$ & $0.6 \%$ & & & & & \\
\hline & $F$ & $2.0 \%$ & $1.0 \%$ & $0.6 \%$ & $0.8 \%$ & $0.2 \%$ & & & & \\
\hline & $F$ & $2.0 \%$ & $0.2 \%$ & $0.6 \%$ & $0.4 \%$ & $1.0 \%$ & $1.2 \%$ & & & \\
\hline & $F$ & $1.8 \%$ & $0.0 \%$ & $0.4 \%$ & $0.2 \%$ & $0.8 \%$ & $1.0 \%$ & $0.2 \%$ & & \\
\hline & KT901831 & $1.4 \%$ & $0.4 \%$ & $0.0 \%$ & $0.2 \%$ & $0.4 \%$ & $0.6 \%$ & $0.6 \%$ & $0.4 \%$ & \\
\hline 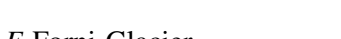 & KT901834 & $1.6 \%$ & $0.6 \%$ & $0.2 \%$ & $0.4 \%$ & $0.6 \%$ & $0.8 \%$ & $0.8 \%$ & $0.6 \%$ & $0.2 \%$ \\
\hline
\end{tabular}

$F$ Forni Glacier

However, they occurred in supraglacial debris and mosses (Fig. 4, Tables S2-S3).

Desiccation and heat stress

The desiccation experiment suggested that low-temperature water and higher concentration of cryoconite increased the probability of recovery of tardigrades. In the first experiment, which compared recovery success in low and room temperature, we found clear differences for tardigrades desiccated in different thermal regimes. Following desiccation, no individuals recovered at room-temperature water or room-temperature water/cryoconite. Following desiccation of 91 individuals, only three recovered in low-temperature water but substantially more in low-temperature water/cryoconite (Fig. 5). In the experiment comparing recovery success in low temperatures between water, little cryoconite, abundant cryoconite and little and abundant sand (as example of different kind of material, see methods), the lowest recovery success $(4.5 \%)$ was detected in pure water. The recovery after desiccation in cryoconite varied between $29.5 \%$ (low amount) and $31.5 \%$ (high amount) and from 23 to $45 \%$ for low and high amount of sand, respectively (Fig. 6). In cryoconite treatments conducted in low temperature, seven tardigrades were hidden or appeared to hide in a cryoconite granule during desiccation (Fig. 7).

\section{Air traps}

No glacial tardigrades were captured after 4 days of trapping, and although other animal taxa were captured on-glacier, and non-glacial tardigrades were captured out off-glacier. After 4 days of exposure, air trap contained the representatives of micro- and macroinvertebrates: Collembola, Acari, Insecta (Diptera, Hymenoptera, Coleoptera) and their remains, Opiliones and Tardigrada. Springtails were the most common in all the traps. The composition of fauna differed between localities, with the highest taxa diversity found in the proglacial field and in the main valley. On the medial moraine only one specimen of eriophyoid mite was found. Tardigrades were found only in the traps located in the valley but represented non-glacier fauna (Macrobiotus sp., Milnesium sp. and Diphascon sp., along with one exuvia with eggs). All detailed results are presented in Table S8.

\section{Discussion}

In this study, we found that cryoconite holes on the Forni Glacier are exclusively dominated by one metazoan group of tardigrades, representing one aquatic species, $H$. klebelsbergi originally described and also known from other glaciers in the Alps (Mihelčič 1959; Dastych et al. 2003; Greven et al. 2005; Dabert et al. 2015). In cryoconite holes investigated worldwide so far, such a domination has never been reported. Arctic and Antarctic glaciers are inhabited by both tardigrades and rotifers, which belong to several species (De Smet and Van Rompu 1994; Grøngaard et al. 1999; Porazińska et al. 2004; Shain et al. 2016; Zawierucha et al. 2016; Sommers et al. 2019) with one finding of rotifers coexisting with mites (Zawierucha et al. 2019a). Such a peculiar dominance of a single group of metazoans in ecosystems was usually observed in extreme ecosystems in 
Fig. 5 Recovery success after desiccation of Hypsibius klebelsbergi in room $\left(16-20{ }^{\circ} \mathrm{C}\right)$ and low $\left(3{ }^{\circ} \mathrm{C}\right)$ temperatures between water and cryoconite

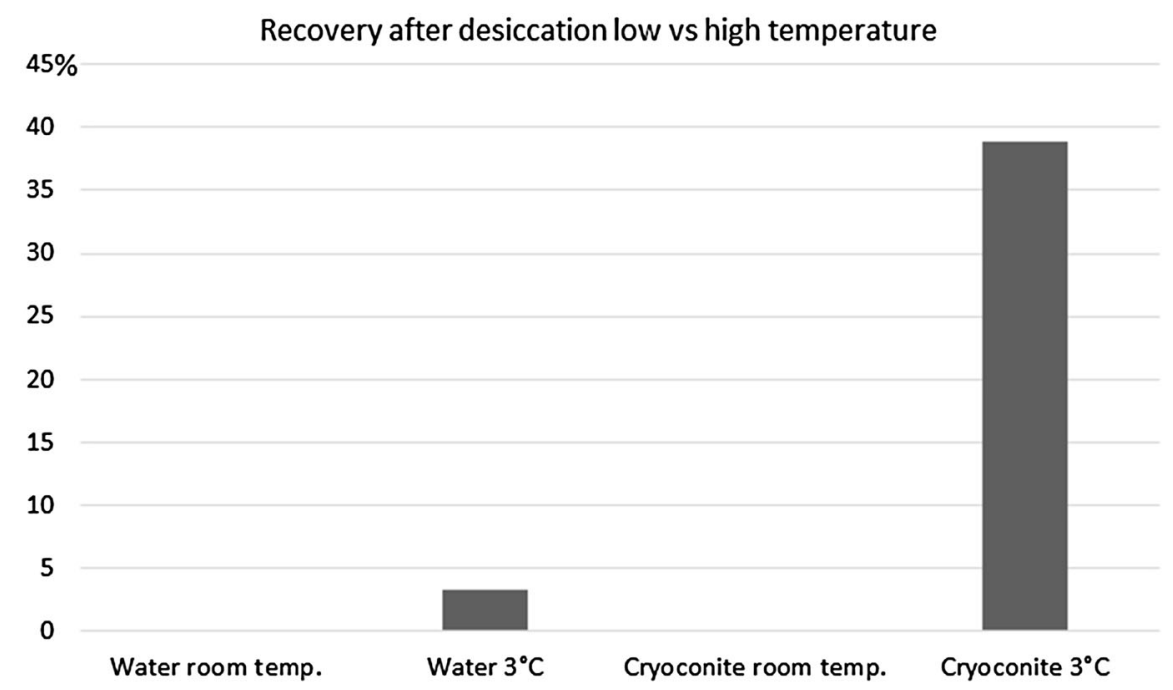

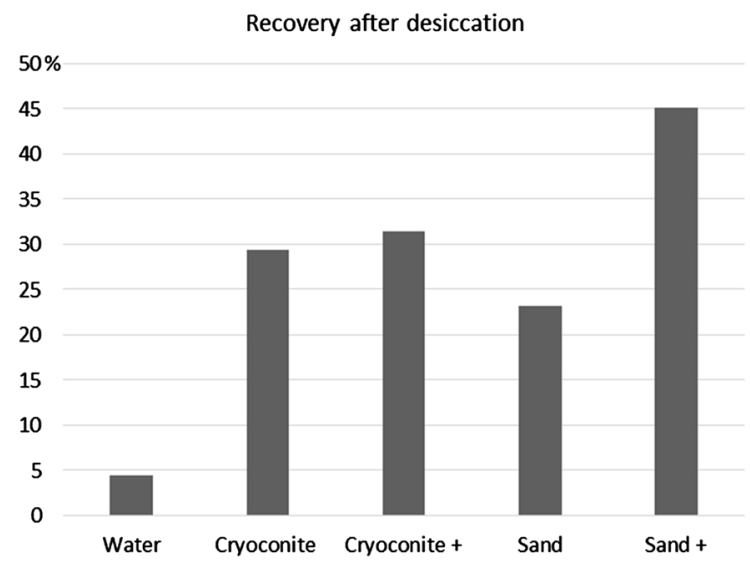

Fig. 6 Recovery success after desiccation of Hypsibius klebelsbergi in low $\left(3^{\circ} \mathrm{C}\right)$ temperature between water, cryoconite and sand ("Cryoconite +" and "Sand +" indicate doubled amount of material in which tardigrades were desiccated)

which animals need sophisticated physiological strategies to survive freezing and desiccation. In glacial ecosystems such exclusive dominance was observed for maritime glaciers in North America where peculiar, black-pigmented oligochaetes called ice worms live, which inhabit englacial zone of glaciers (Shain et al. 2001; Dial et al. 2016). In non-glacial habitats, such a domination was observed in Antarctic deserts. For instance, McMurdo Dry Valleys are mostly dominated by nematodes (Porazińska et al. 2002; Powers et al. 1994, 1995). Exclusive domination of an ecosystem by tardigrades is known only from small Antarctic mosses collected from stones (Convey and

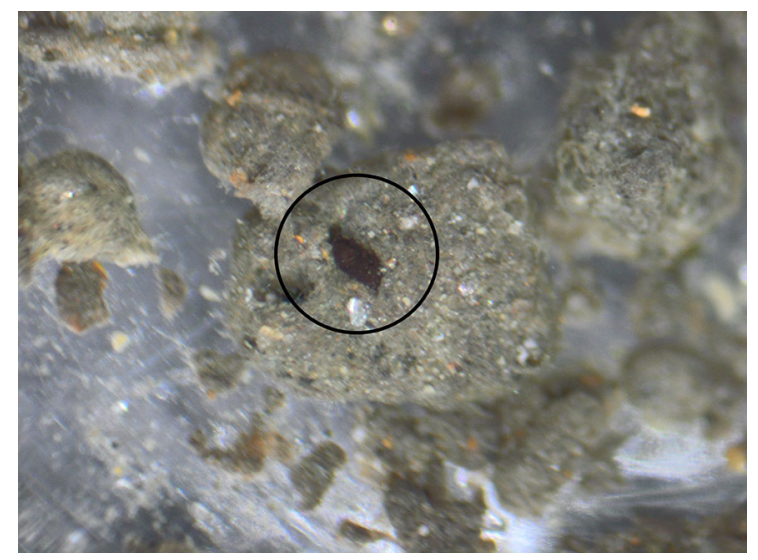

Fig. 7 Hypsibius klebelsbergi hiding in cryoconite granule. Picture taken in water during examination of well after 1 week of desiccation

McInnes 2005). Such a phenomenon remains a topic of debate and is explained by the competition for food and the lack of physiological adaptation to survive in harsh ecosystems (Ring and Tesar 1981; Andriuzzi et al. 2018; Zawierucha et al. 2018b). In terms of the Forni Glacier, such an unexpected domination by tardigrades may be explained by the reduction in common competitors for tardigrades on glaciers, namely rotifers which may compete for food in cryoconite holes. However, in cryoconite from the Alps, Dastych et al. (2003) reported the presence of rotifers which, although low, cannot be ignored. Apart from cryoconite holes, tardigrades were highly abundant in wet supraglacial debris mixed with cryoconite 
material. A high concentration of cryoconite granules in supraglacial debris is probably connected mostly with the collapsing of cryoconite holes and the redistribution of material on ice surface (Zawierucha et al. 2019b). In supraglacial debris, we found many small, most probably newly born tardigrades, which suggests that, as long as the supraglacial debris is wet, it forms a suitable habitat for tardigrades. Nevertheless, springtails and rotifers inhabited these environments too, which may indicate a potential competition for food between taxa in supraglacial debris which constitute temporary habitats, as well as more complex trophic relations as the ones reported in cryoconite holes on Forni.

According to Dastych et al. (2003), the abundance of tardigrades in glacier pools of water (cryoconite holes) in the Alps consisted of up to 75 individuals and up to $3.60 \mathrm{ind} . / \mathrm{cm}^{3}$ of meltwater on Rotmoosfemer in the Ötztal Alps (Austria) (Dastych et al. 2003). These values are lower than those detected in the present study. The densities of tardigrades on Forni are comparable with other records of these animals on glaciers in the Arctic and comparable with their abundance in terrestrial samples (Zawierucha et al. 2019a). This in turn may imply that, despite harsh conditions on glaciers reflected by low diversity of animals, cryoconite is a suitable habitat for coldloving water bears.

Hypisbius klebelsbergi is very sensitive to higher temperatures. We observed that while picking up animals from petri dishes in room temperatures, after a few minutes they stopped being active and coiled (started entering cryptobiosis or encystation), or more probably they were dying. What laboratory experiments showed as well is that the animals did not recover after desiccation in room temperature. Thus, low densities and frequency of tardigrades in mosses collected from supraglacial stones may be the effect of limiting factors such as temperature and moisture. Mosses on stones are often exposed to the sun. Even when surrounded by ice, the stones are warmer and may form, in mosses overgrown them, unfavourable conditions for typical glacier-dwelling tardigrades. The presence of tardigrades on dirt cones seems to be more accidental. We found many remains of tardigrades bodies, most probably wind-blown to the cones. However, we still encountered well-preserved animals, and it seems that in some circumstances they may inhabit debris. This peculiarity can be strictly connected to the origin and evolution of these structures: this sediment has an englacial origin formed by the accumulation of supraglacial debris on the bottom of a glacier moulin. Moulins are nearly vertical shafts within a glacier that drain water from the glacier surface: the remains and active tardigrades can be accumulated in debris carried by surface melting water. Once the dirt cone emerged, consequently to the ice melting, the colonisation of new tardigrades could take place and due to the cold thermal outcome from the ice core of dirt cones, tardigrades in debris could have a stable, relatively cold and humid environment. Although tardigrades were present in mosses and dirt cones, the conditions for them found therein are definitely less favourable than those in cryoconite holes and supraglacial debris (gravel mixed with cryoconite).

Until now, obligate freshwater tardigrade species were considered to undergo limited or no cryptobiosis and to be desiccation sensitive (Rebecchi et al. 2009; Nelson et al. 2019). Yet, many limno-terrestrial tardigrades which need a film of water to be active are able to survive freezing and desiccation (Guidetti et al. 2012b; Guidetti and Jönsson 2002; Jönsson and Rebecchi 2002). Since tardigrades on glaciers inhabit permanently aquatic/wet habitats, we can assume that they are freshwater species able to survive desiccation. Still, their recovery success is small in comparison with that of other limno-terrestrial water bears (Bertolani et al. 2004; Schill and Hengherr 2019; Wełnicz et al. 2011), and tardigrade species best adapted to desiccation are the ones inhabiting xeric environments, for example, lichens (Rebecchi et al. 2006). Instead of typical anhydrobiosis, H. klebelsbergi most probably entered encystation, which is typical for freshwater species (Bertolani et al. 2004). Nevertheless, a deeper analysis is necessary, and it will be discussed in our future studies.

Our laboratory observations and the results of experiments indicate that $H$. klebelsbergi is temperature sensitive and, in spite of its limited adaptation to desiccation, it needs sediments and low temperatures to successfully enter and recover from a dormant state. Low recovery success in pure water may be explained by the fact that cryoconite and sand keep moisture longer and there is no direct and abrupt transition between humid and dry environments. Therefore, in such sediments animals have more time to enter a dormant state. The findings of a few tardigrades in 
granules (with anterior part of the body located in granule), after desiccation may indicate that in a natural environment, when cryoconite is removed from holes and dries on ice, such behaviour facilitates survival against desiccation (avoidance of dessication). It confirms our assumption that recovery success depends on the presence/absence of sediments during entering a dormant state, and the type of material (cryoconite vs sand) seems not to play any role. Most probably it is temperature that limits the presence of glacier tardigrades even in suitable habitats such as rock pools or submerged mosses in front of a glacier, where there is the lack of temperature buffer, e.g. ice maintaining a cold environment. However, we cannot rule out the possibility that, apart from physiological barriers, other factors such as competition for food or the presence of predators may reduce the number of glacier-dwelling tardigrades.

Generally, the dispersal of tardigrades is a poorly known phenomenon (Jørgensen et al. 2007; Gąsiorek et al. 2019; Fontaneto 2019). Previous studies have suggested that wind is an important factor influencing the dispersal of animals, both on and to glaciers (Dabert et al. 2015; Zawierucha et al. 2018a, b). The mechanism of wind transport of these animals remains unexplored. Zawierucha et al. (2018b) showed that most probably wind may transport glacier tardigrades even to distant glaciers (more than $1000 \mathrm{~km}$ ). The survival of desiccation in sediments under low temperatures may play a significant role in the process of dispersal in water bears. As suggested by Nkem et al. (2005), during cryptobiosis due to the removal of water from the body, the weight dropped significantly which facilitated dispersal with wind. The identification of eight COI haplotypes from only eight individuals suggests that genetic diversity within the species may be considerable. Surprisingly, we found a higher genetic diversity on Forni than Dabert et al. (2015) between the specimens of $H$. klebelsbergi from Langtalerferner and Ramolferner (Austrian Alps). Sharing the same as well as distinctly different haplotypes between distant glaciers in the Alps may indicate effective dispersal abilities of $H$. klebelsbergi. However, owing to physiological constraints, we suspect dispersal might have taken place only when tardigrades desiccated in sediments and were passively transported by cold wind. On the other hand, it should be taken into consideration that during the last glacial maximum the Alps were covered by vast ice fields and the same haplotypes may have been shared between glaciers. The unique sequences on Forni may thus only indicate that $H$. klebelsbergi is evolutionary old and has just started differentiation from a large maternal population.

In a supraglacial zone, passive dispersal of tardigrades is less problematic. They are most probably transported by streams and melting water as was shown for tardigrades in the Arctic (Zawierucha et al. 2019b) and in the Alps (Dastych et al. 2003).

Contrary to our expectations, we did not find rotifers or nematodes in the traps. Still, the lack of these groups may result from a short time span of keeping traps in the field. On the other hand, we found unexpectedly high tardigrade diversity represented by three taxa. Tardigrades were found only in the traps from a transition zone between a valley and the proglacial field, where the traps were installed close to rocks covered by moss patches and where wind gusts were the strongest, most probably blowing specimens from the mosses. Sudzuki (1972) proved that wind gusts with speed $2 \mathrm{~m} / \mathrm{s}$ rarely influence passive dispersal of tardigrades; however, the speed of wind and speed of wind gusts during field works exceeded $10 \mathrm{~m} / \mathrm{s}$ (authors unpublished data), which most probably facilitated removal of invertebrates from moss patches. Although glacier tardigrades were not found in the traps, a single individual was extracted from medial moraine gravel and most probably was passively delivered there by wind. Gravel on moraines is not a typical habitat either for terrestrial or for aquatic tardigrades.

Our studies and previous surveys (Dastych et al. 2003; Greven et al. 2005) underlined that Hypsibius klebelsbergi is a typical glacier-dwelling tardigrade, with findings of this species only on glacier. Our studies broadly increase the knowledge on this taxon showing densities, habitat preferences, adaptations to desiccation and links with its dispersal. Future studies on glacier tardigrades in the Alps should pay more attention particularly to biomass, the role of these animals in matter flow and their dispersal between glaciers.

Acknowledgements Authors would like to thanks professor Diane Nelson and second anonymous reviewer for their comments and improvements of manuscript. K.Z. would like to thanks Łukasz Michalczyk for consultation on laboratory experiment design and Nicoletta Makowska for help during pilot study. Studies on tardigrades on Forni are conducted within project NCN 2018/31/B/NZ8/00198 to K.Z. 
Open Access This article is distributed under the terms of the Creative Commons Attribution 4.0 International License (http:// creativecommons.org/licenses/by/4.0/), which permits unrestricted use, distribution, and reproduction in any medium, provided you give appropriate credit to the original author(s) and the source, provide a link to the Creative Commons license, and indicate if changes were made.

\section{References}

Ambrosini R, Musitelli F, Navarra F et al (2017) Diversity and assembling processes of bacterial communities in cryoconite holes of a Karakoram glacier. Microbiol Ecol 73:827-837. https://doi.org/10.1007/s00248-016-0914-6

Andriuzzi WF, Adams BJ, Barrett JE, Virginia RA, Wall DH (2018) Observed trends of soil fauna in the Antarctic Dry Valleys: early signs of shifts predicted under climate change. Ecology 99:312-321. https://doi.org/10.1002/ecy. 2090

Anesio AM, Laybourn-Parry J (2012) Glaciers and ice sheets as a biome. TrEE 4:219-225

Azzoni RS, Fugazza D, Zennaro M et al (2017) Recent structural evolution of Forni Glacier tongue (Ortles-Cevedale Group, Central Italian Alps). J Maps 13:870-878. https://doi.org/ 10.1080/17445647.2017.1394227

Bagshaw EA, Tranter M, Fountain AG et al (2007) Biogeochemical evolution of cryoconite holes on Canada Glacier, Taylor Valley, Antarctica. J Geophys Res 112:G04S35. https://doi.org/10.1029/2007jg000442

Bertolani R, Guidetti R, Jönsson KI, Altiero T, Boschini D, Rebecchi L (2004) Experiences on dormancy in tardigrades. J Limnol 63:16-25

Convey P, McInnes SJ (2005) Exceptional tardigrade-dominated ecosystems in Ellsworth Land, Antarctica. Ecology 86:519-527. https://doi.org/10.1890/04-0684

Convey P, Chown SL, Clarke A et al (2014) The spatial structure of Antarctic biodiversity. Ecol Monogr 84:203-244. https://doi.org/10.1890/12-2216.1

Convey P, Coulson SJ, Worland MR, Sjöblom A (2018) The importance of understanding annual and shorter-term temperature patterns and variation in the surface levels of polar soils for terrestrial biota. Polar Biol 41:1587-1605. https://doi.org/10.1007/s00300-018-2299-0

Cook J, Edwards A, Hubbard A (2015) Biocryomorphology: integrating microbial processes with ice surface hydrology, topography and roughness. Front Earth Sci 3:78

Cook JM, Edwards A, Takeuchi N, Irvine-Fynn T (2016) Cryoconite. The dark biological secret of the cryosphere. Prog Phys Geogr 40:1-46

Coulson SJ, Midgley NG (2012) The role of glacier mice in the invertebrate colonisation of glacial surfaces: the moss balls of the Falljo kull, Iceland. Polar Biol 35:1651-1658

Dabert J, Ehrnsberger R, Dabert M (2008) Glaucalges tytonis sp. nov. (Analgoidea: Xolalgidae) from the barn owl Tyto alba (Strigiformes: Tytonidae): compiling morphology with DNA barcode data for taxa descriptions in mites (Acari). Zootaxa 1719:41-52
Dabert M, Dastych H, Dabert J (2015) Molecular data support the dispersal ability of the glacier tardigrade Hypsibius klebelsbergi Mihelcic, 1959 across the environmental barrier (Tardigrada). Mitt Hamb Zool Mus Inst 17:233-240

Dastych H (1980) Niesporczaki (Tardigrada) Tatrzanskiego Parku Narodowego. Monogr Fauny Polski 9:1-232

Dastych H, Kraus HJ, Thaler K (2003) Redescription and notes on the biology of the glacier tardigrade Hypsibius klebelsbergi Mihelcic, 1959 (Tardigrada), based on material from Ötztal Alps, Austria. Mitt Hamb Zool Mus Inst 100:73-100

De Smet WH, Van Rompu EA (1994) Rotifera and Tardigrada from some cryoconite holes on a Spitsbergen (Svalbard) glacier. Belg J Zool 124:27-37

Degma P (2019) Field and laboratory methods. Field and laboratory methods. In: Schill RO (ed) Water bears: the biology of tardigrades. Springer, Berlin, pp 349-369

Degma P, Bertolani R, Guidetti R (2019) Actual checklist of Tardigrada species. Retrieved from:http://www.tardigrada. modena.unimo.it/miscellanea/Actual\%20checklist\% 20of\%20Tardigrada.pdf (Accessed 30 March 2019)

Dial RJ, Becker M, Hope AG et al (2016) The role of temperature in the distribution of the glacier ice worm, Mesenchytraeus solifugus (Annelida: Oligochaeta: Enchytraeidae). Arct Antarct Alp Res 48:199-211

Ferrario C, Pittino F, Tagliaferri I et al (2017) Bacteria contribute to pesticide degradation in cryoconite holes in an Alpine glacier. Environ Pollut 230:919-926

Fontaneto D (2019) Long-distance passive dispersal in microscopic aquatic animals. Mov Ecol 7:10. https://doi.org/10. 1186/s40462-019-0155-7

Fountain A, Tranter M, Nylen TH, Lewis KJ, Mueller DR (2004) Evolution of cryoconite holes and their contribution to melt water runoff from glaciers in the McMurdo Dry Valleys, Antarctica. J Glaciol 50:35-45

Franzetti F, Tagliaferri I, Gandolfi I et al (2016) Light-dependent microbial metabolisms drive carbon fluxes on glacier surfaces. ISME J 10:2984

Franzetti A, Navarra F, Tagliaferri I et al (2017) Potential sources of bacteria colonizing the cryoconite of an Alpine glacier. PLoS ONE 12(3):e0174786. https://doi.org/10. 1371/journal.pone.0174786

Gąsiorek P, Vončina K, Michalczyk Ł (2019) Echiniscus testudo (Doyère, 1840) in New Zealand: anthropogenic dispersal or evidence for the "Everything is Everywhere" hypothesis? N Z J Zool 46:174-181

Greven H, Dastych H, Kraus HJ (2005) Notes on the integument of the glacier-dwelling tardigrade Hypsibius klebelsbergi Mihelcic, 1959 (Tardigrada). Mitt Hamb Zool Mus Inst 102:11-20

Grøngaard A, Pugh PJA, McInnes SJ (1999) Tardigrades, and other cryoconite biota, on the Greenland ice sheet. Zool Anz 238:211-214

Guidetti R, Jönsson KI (2002) Long-term anhydrobiotic survival in semi-terrestrial micrometazoans. J Zool 257:181-187

Guidetti R, Altiero T, Marchioro T et al (2012a) Form and function of the feeding apparatus in Eutardigrada (Tardigrada). Zoomorphology 131:127-148. https://doi.org/10. 1007/s00435-012-0149-0 
Guidetti R, Rizzo AM, Altiero T, Rebecchi L (2012b) What can we learn from the toughest animals of the Earth? Water bears (tardigrades) as multicellular model organisms in order to perform scientific preparations for lunar exploration. Planet Space Sci 74(1):97-102

Guil N, Sanchez-Moreno S (2013) Fine-scale patterns in micrometazoans: tardigrade diversity, community composition and trophic dynamics in leaf litter. Syst Biodiver 11:181-193. https://doi.org/10.1080/14772000.2013. 798370

Guil N, Sánchez-Moreno S, Machordom A (2009) Local biodiversity patterns in micrometazoans: Are tardigrades everywhere? Syst Biodiver 7:259-268

Hall TA (1997) BIOEDIT: a user-friendly biological sequence alignment editor and analysis program for Windows 95/98/ NT. Nucleic Acids Symp Ser 41:95-98

Hallas TE, Yeates GW (1972) Tardigrada of the soil and litter of a Danish beech forest. Pedobiologia 12:287-304

Hodson A, Anesio AM, Tranter M et al (2008) Glacial ecosystems. Ecol Monogr 78:41-67

Hodson A, Brock B, Pearce D et al (2015) Cryospheric ecosystems: a synthesis of snowpack and glacial research. Environ Res Lett 10:110201. https://doi.org/10.1088/17489326/10/11/110201

Jönsson KI, Rebecchi L (2002) Experimentally induces anhydrobiosis in the tardigrade Richtersius coronifer: Phenotypic factors affecting survival. J Exp Zool 293:578-584

Jørgensen A, Mobjerg N, Kristensen RM (2007) A molecular study of the tardigrade Echiniscus testudo (Echiniscidae) reveals low DNA sequence diversity over a large geographical area. J Limnol 66:77-83

Kaczmarek Ł, Michalczyk Ł, McInnes SJ (2016) Annotated zoogeography of non-marine Tardigrada. Part III: North America and Greenland. Zootaxa 4203(1):1-249

Kumar S, Stecher G, Tamura K (2016) MEGA7: Molecular evolutionary genetics analysis version 7.0. Mol Biol Evol 33:1870-1874

Liu Y, Vick-Majors TJ, Priscu JC et al (2017) Biogeography of cryoconite bacterial communities on glaciers of the Tibetan Plateau. FEMS Microbiol Ecol. https://doi.org/10.1093/ femsec/fix 072

Łokas E, Zawierucha K, Cwanek A et al (2018) The sources of high airborne radioactivity in cryoconite holes from the Caucasus (Georgia). Sci Rep. https://doi.org/10.1038/ s41598-018-29076-4

McInnes S, Pugh P (2019) Tardigrade biogeography. In: Schill RO (ed) Water bears: the biology of tardigrades. Springer, Berlin, pp 115-129

McInnes SJ, Michalczyk Ł, Kaczmarek Ł (2017) Annotated zoogeography of non-marine Tardigrada. Part IV: Africa. Zootaxa 4284(1):1-7

Mihelcic F (1959) Zwei neue Tardigraden aus der Gattung Hypsibius Thulin aus Osttirol (Österreich). Systematisches zur Gattung Hypsibius Thulin. Zool Anz 163:254-261

Mueller DR, Vincent WF, Pollard WH, Fristen CH (2001) Glacial cryoconite ecosystems: a bipolar comparison of algal communities and habitats. Nov Hedwig Beih 123:173-197

Nelson DR, Guidetti R, Rebecchi L (2015) Phylum Tardigrada. In: Rogers DC, Thorp J (eds) Ecology and general biology. Academic Press, New York, pp 347-380
Nelson D, Bartels P, Guil N (2019) Tardigrade ecology. In: Schill RO (ed) Water bears: the biology of tardigrades. Springer, Cham, pp 163-210

Nkem JN, Wall DH, Virginia RA et al (2005) Wind dispersal of soil invertebrates in the McMurdo Dry Valleys, Antarctica. Polar Biol 29:346-352

Perini L, Gostincar C, Anesio AM, Williamson C, Tranter M, Gunde-Cimerman N (2019) Darkening of the Greenland Ice Sheet: fungal abundance and diversity are associated with algal bloom. Front Microbiol 10:557. https://doi.org/ 10.3389/fmicb.2019.00557

Pittino F, Maglio M, Gandolfi I et al (2018) Bacterial communities of cryoconite holes of a temperate alpine glacier show both seasonal trends and year-to-year variability. Ann Glaciol. https://doi.org/10.1017/aog.2018.16

Porazińska DL, Wall DH, Virginia RA (2002) Population age structure of nematodes in the Antarctic Dry Valleys: perspectives on time, space, and habitat suitability. Arct Antarct Alp Res 34:159-168. https://doi.org/10.2307/ 1552467

Porazińska DL, Fountain AG, Nylen TH, Tranter M, Virginia RA, Wall DH (2004) The biodiversity and biogeochemistry of cryoconite holes from McMurdo dry valley glaciers, Antarctica. Arct Antarct Alp Res 36:84-91

Powers LE, Freckman DW, Virginia RA (1994) Depth distribution of soil nematodes in Taylor Valley, Antarctica. Antarct J US 29:175-176

Powers LE, Freckman DW, Virginia RA (1995) Spatial distribution of nematodes in polar desert soils of Antarctica. Pol Biol 15:325-333

Rebecchi L, Guidetti R, Borsari S, Altiero T, Bertolani R (2006) Dynamics of long-term anhydrobiotic survival of lichendwelling tardigrades. Hydrobiologia 558:23-30

Rebecchi L, Boschini D, Cesari M, Lencioni V. Bertolani R, Guidetti R (2009) Stress response of a boreo-alpine species of tardigrade, Borealibilis zetlandicus (Eutardigrada, Hypsibiidae). J Limnol 81:64-70

Ring RA, Tesar D (1981) Adaptations to cold in Canadian arctic insects. Cryobiology 18:199-211

Rivas JA Jr, Schröder T, Gill TE, Wallace RL, Walsh EJ (2019) Anemochory of diapausing stages of microinvertebrates in North American drylands. Fresh Biol. https://doi.org/10. 1111/fwb.13306

Schill RO, Hengherr S (2019) Environmental adaptations: desiccation tolerance. In: Schill RO (ed) Water bears: the biology of tardigrades. Springer, Berlin, pp 273-293

Shain DH, Mason TA, Farrell AH, Michalewicz LA (2001) Distribution and behavior of ice worms (Mesenchytraeus solifugus) in south-central Alaska. Can J Zool 79:1813-1821

Shain DH, Halldórsdóttir K, Pálsson F et al (2016) Colonization of maritime glacier ice by bdelloid Rotifera. Mol Phylo Evol 98:280-287

Sommers P, Darcy JL, Porazinska DL et al (2019) Comparison of microbial communities in the sediments and water columns of frozen cryoconite holes in the McMurdo Dry Valleys. Antarctica. Front Microbiol 10:65. https://doi.org/ 10.3389/fmicb.2019.00065

Stibal M, Lawson EC, Lis GP, Mak KM, Wadham JL, Anesio AM (2010) Organic matter content and quality in 
supraglacial debris across the ablation zone of the Greenland ice sheet. Ann Glaciol 51:1-8

Stibal M, Schostag M, Cameron KA et al (2015) Different bulk and active bacterial communities in cryoconite from the margin and interior of the Greenland ice sheet: Bulk and active bacteria in Greenland cryoconite. Environ Microbiol Rep 7:293-300. https://doi.org/10.1111/1758-2229.12246

Sudzuki M (1972) An analysis of colonization in freshwater micro-organisms. II. Two simple experiments on the dispersal by wind. Jpn J Ecol 22(5):222-225

Takeuchi N, Kohshima S, Yoshimura Y et al (2000) Characteristics of cryoconite holes on a Himalayan glacier, Yala Glacier Central Nepal. Bull Glaciol Res 17:51-59

Takeuchi N, Sakaki R, Uetake J et al (2018) Temporal variations of cryoconite holes and cryoconite coverage on the ablation ice surface of Qaanaaq Glacier in northwest Greenland. Ann Glaciol 59(77):21-30

Wełnicz W, Grohme MA, Kaczmarek Ł, Schill RO, Frohme M (2011) Anhydrobiosis in tardigrades - the last decade. J Insect Physiol 57(5):577-583

Wharton RA, McKay CP, Simmons GM, Parker BC (1985) Cryoconite holes on glaciers. Bioscience 35:449-503

Zawierucha K, Ostrowska M, Vonnahme TR et al (2016) Diversity and distribution of Tardigrada in Arctic cryoconite holes. J Limnol 75(3):545-559
Zawierucha K, Buda J, Pietryka M et al (2018a) Snapshot of micro-animals and associated biotic and abiotic environmental variables on the edge of south-west Greenland ice sheet. Limnology 19:141-150

Zawierucha K, Stec D, Lachowska-Cierlik D, Takeuchi N, Li Z, Michalczyk $€$ (2018b) High mitochondrial diversity in a new water bear species (Tardigrada: Eutardigrada) from mountain glaciers in central Asia, with the erection of a new genus Cryoconicus. Ann Zool 68:179-201

Zawierucha K, Buda J, Fontaneto D et al (2019a) Fine-scale spatial heterogeneity of invertebrates within cryoconite holes. Aquat Ecol 53(2):179-190

Zawierucha K, Buda J, Nawrot A (2019b) Extreme weather event results in the removal of invertebrates from cryoconite holes on an Arctic valley glacier (Longyearbreen, Svalbard). Ecol Res 34(3):370-379

Publisher's Note Springer Nature remains neutral with regard to jurisdictional claims in published maps and institutional affiliations. 